\title{
Epidemiologic and clinical features of chronic hepatitis B virus infection in 8 Canadian provinces: a descriptive study by the Canadian HBV Network
}

\author{
Carla S. Coffin MD MSc, Alnoor Ramji MD, Curtis L. Cooper MD MSc, David Miles MD, \\ Karen E. Doucette MD MSc, Philip Wong MD, Edward Tam MD, David K. Wong MD, \\ Alexander Wong MD, Sylvester Ukabam MD, Robert J. Bailey MD, Keith Tsoi MD, Brian Conway MD, \\ Lisa Barrett MD PhD, Tomasz I. Michalak MD PhD, Stephen E. Congly MD MSc, Gerald Minuk MD, \\ Kelly Kaita MD, Erin Kelly MD, Hin Hin Ko MD, Harry L.A. Janssen MD PhD, Julia Uhanova PhD, \\ Brendan C. Lethebe MSc, Sarah Haylock-Jacobs PhD, Mang M. Ma MD, Carla Osiowy PhD,
} Scott K. Fung MD; for the Canadian HBV Network

\section{Abstract}

Background: Published Canadian epidemiologic data on hepatitis B virus (HBV) infection include single-centre studies or are focused on Indigenous populations. We performed a study to characterize the demographic and clinical features, liver disease status and treatment of people with chronic hepatitis B in Canada.

Methods: In this descriptive, opportunistic, cross-sectional study, available data for people known to be monoinfected with HBV were collected by the Canadian HBV Network from existing clinical databases (2012-2019), with support from the National Microbiology Laboratory, Public Health Agency of Canada. Data were collected in all provinces with the exception of New Brunswick and Prince Edward Island. We analyzed the data using parametric and nonparametric statistical methods, with a significance level of $p<0.05$.

Results: In the 9380 unique patient records reviewed, the median age was 48 years, and 5193 patients (55.4\%) were male. Ethnicity information was available for 7858 patients, of whom 5803 (73.8\%) were Asian, $916(11.6 \%)$ were black and $914(11.6 \%)$ were white. Most of those tested (5556/6796 [81.8\%]) were negative for HBV e-antigen, and most of those with fibrosis data (3481/4260 [81.7\%]) had minimal liver fibrosis, with more advanced fibrosis noted in older people (>40 yr). Of the 980 patients with genotype data, 521 $(53.2 \%)$ had genotype B or C infection. Most of the 9241 patients with known confirmed treatment status received tenofovir disoproxil fumarate (1655 [17.9\%]), lamivudine (1434 [15.5\%]) or entecavir (548 [5.9\%]).

Interpretation: Based on available data, Canadian patients with chronic hepatitis B are predominantly Asian and negative for HBV e-antigen, and have genotype B or C infection. Interprovincial variations were noted in antiviral treatment regimen. This multicentre nationwide study provides data regarding patients with chronic hepatitis B and may inform future studies on the epidemiologic features of HBV infection in Canada.

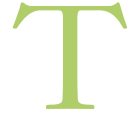
he hepatitis B virus (HBV) is a major human pathogen, with 257 million chronic carriers worldwide especially in Asia and Sub-Saharan Africa - who remain at risk for cirrhosis, liver failure and hepatocellular carcinoma. ${ }^{1,2}$ There are 8 major HBV genotypes, with a specific geographic and ethnic distribution, which have been linked to disease outcomes and response to antiviral therapy. ${ }^{3}$ Hepatitis B is reportable to the Canadian Notifiable Disease Surveillance System, ${ }^{4}$ yet reliable epidemiologic data are limited owing to the lack of standardized reporting practices and with reporting of only acutely infected people. A Public Health Agency of Canada report on hepatitis B and C in Canada in 2013 lacks data from 2 provinces (Newfoundland and Labrador, Prince Edward Island) and 2 territories
(Northwest Territories, Nunavut). ${ }^{5}$ Data from the Public Health Agency of Canada show lower estimates of chronic hepatitis B prevalence and incidence rate in British Columbia than those reported by the BC Centre for Disease Control owing to disparate reporting practices. ${ }^{6}$ In a report from the Canadian Liver Foundation, it was estimated that 250000

Competing interests: See the end of the article.

This article has been peer reviewed.

Correspondence to: Carla Coffin, cscoffin@ucalgary.ca

CMAJ Open 2019. DOI:10.9778/cmajo.20190103 
460000 Canadians have chronic hepatitis B, with highest rates found in urban centres. ${ }^{7}$ The prevalence of acute and chronic HBV infection has declined in Canadian-born people with the advent of universal childhood vaccination, in the mid-1990s. A seroepidemiologic survey of Arctic Indigenous populations, historically considered to be hyperendemic for HBV infection, showed a nonendemic prevalence of $1.2 \%$, yet a substantial number of people were found to have lower than expected vaccine-based immunity, with unknown clinical characteristics. ${ }^{8}$ The 2016 Canada long-term census survey showed considerable ethnocultural diversity within Canada, with 1 in 5 Canadians (21.9\%) either a landed immigrant or a permanent resident. ${ }^{9}$ Importantly, most newcomers were from Asia (61\%), with Africa as the second-highest (13.4\%) source for recent immigrants, especially highly HBV-endemic countries. Most new Canadians live in established home-country communities in large urban centres (e.g., Toronto, Montréal, Vancouver). Interestingly, there is increasing settlement in less-populous regions (e.g., prairie and Atlantic provinces) owing to economic factors such as job growth in the energy sector or under special provincial nominee programs to encourage population growth (e.g., Manitoba "growing through immigration" [www.immigratemanitoba.com]). This evolving Canadian demographic landscape highlights the need for updated large-scale epidemiological data on HBV infection and the associated disease burden in Canada.

The current study was an opportunistic, cross-sectional descriptive study using available clinical data for people with chronic hepatitis B in Canada. Our study aim was to characterize the demographic and clinical features, virological outcomes and treatment of the more than 9000 patients with hepatitis B followed in diverse academic and community care clinics nationwide. The data collected will facilitate further hypothesis-generating studies to be conducted on hepatitis B in Canada.

\section{Methods}

\section{Study design}

The Canadian HBV Network was formed in 2016 and received official endorsement by the Canadian Association for the Study of the Liver in 2017. It includes 21 academic and community clinical care centres for patients with hepatitis B in 8 Canadian provinces, supported by provincial as well as national reference laboratories (i.e., National Microbiology Laboratory, Public Health Agency of Canada) (Box 1). The network's mission is to 1) improve treatment and control of hepatitis B in Canada, 2) advance the understanding of HBV infection and disease natural history, 3) promote collaboration on national hepatitis B studies and databases and 4) enhance and inform research and educational opportunities on HBV infection and its consequences.

In this descriptive, opportunistic, cross-sectional study, we collated data for patients positive for serum HBV surface antigen and seen in clinic between Jan. 1, 2012, and May 3, 2019 , from information submitted by participating sites to

\section{Box 1: The 21 sites involved in the Canadian HBV Network}

Sites that provided clinical data or laboratory data or both to the current study

1. Department of Medicine, University of British Columbia, Vancouver, BC (1323 patients)

2. LAIR Centre, Vancouver, BC (194 patients)

3. Vancouver Infectious Diseases Centre, BC (18 patients)

4. Division of Infectious Diseases, University of Alberta, Edmonton, Alta. (241 patients)

5. Bailey Health Clinic, Edmonton, Alta. (87 patients)

6. Liver Unit, University of Calgary, Calgary, Alta. (1486 patients)

7. Division of Infectious Diseases, University of Saskatchewan, Regina Qu'Appelle Health Region, Sask. (112 patients)

8. Regina General Hospital, Regina, Sask. (67 patients)

9. Department of Internal Medicine, University of Manitoba, Winnipeg, Man. (1051 patients)

10. National Microbiology Laboratory, Public Health Agency of Canada, Winnipeg, Man. (laboratory testing)

11. McMaster University/St. Joseph's Healthcare, Hamilton, Ont. (80 patients)

12. University of Toronto, Toronto Centre for Liver Disease, Toronto, Ont. (3710 patients)

13. University of Ottawa, Ottawa Hospital Research Institute, Ottawa, Ont. (847 patients)

14. McGill University, Montréal, Que. (132 patients)

15. Dalhousie University, Halifax, NS (19 patients)

16. Memorial University, St. John's, Nfld. (13 patients)

Sites with recent data-sharing agreements or provincial/ hospital laboratories that did not contribute data to the current study

1. Providence Health Care (Medical Microbiology)/BC Centre for Disease Control, Vancouver, BC

2. Division of Gastroenterology and Hepatology, University of Alberta, Edmonton, Alta.

3. Western University, London, Ont.

4. Toronto Liver Centre, North York General Hospital, Toronto, Ont.

5. Laval University, Sainte-Foy, Que.

the data coordinating centre (University of Calgary). Data sources included manual review of physician paper charts at local sites and submission to a Web-based portal, or data downloads from existing stand-alone clinical databases (i.e., Microsoft Access or Excel; Vancouver, Calgary, Winnipeg, Toronto, Ottawa). In Alberta, administrative data on demographic characteristics and laboratory data were collected for 3 participating sites from the Alberta Health Services data repository, as previously described. ${ }^{10}$ Crosssectional data analysis was done on the most recent patient record submitted. Fifteen sites submitted clinical data from 8 provincial health jurisdictions. The data were downloaded and merged into a single Excel spreadsheet or copied manually, verified and analyzed in R 3.5.2 (R Foundation for Statistical Computing) by 2 investigators (S.H.-J. and B.C.L.) for completeness and quality. The Canadian HBV Network coordinator (S.H.-J.) has performed site visits and monitoring 
checks for accuracy. All data entry coordinators were trained, and they follow a database guidance document.

\section{Data elements}

We reviewed available records of adult patients with known chronic hepatitis B. Patients were excluded from analysis if they were coinfected with hepatitis $\mathrm{C}$ virus, hepatitis delta virus or HIV. Available data elements included demographic characteristics (age, sex and, in some cases, ethnicity) and most recent tests for HBV DNA, HBV e-antigen (HBeAg), HBV genotype, alanine aminotransferase, liver stiffness measurement via transient elastography (FibroScan, Echosens) and antiviral therapy history. Laboratory testing was performed through provincial diagnostic laboratories as per standard of care. Hepatitis B virus genotyping is not done in routine clinical practice; however, some data were available retrospectively (including a data subset from a previously published study ${ }^{11}$ ) or were determined prospectively for this study at the National Microbiology Laboratory by in-house direct population sequencing and phylogenetic analysis and/or reverse hybridization assay (Inno-LiPa, Innogenetics).

\section{Statistical analysis}

We summarized measured variables with mean, count and $95 \%$ confidence interval; comparisons were done with $t$ tests. We summarized categorical variables using proportion, count and 95\% confidence interval; comparisons were done with $\chi^{2}$ tests. The comparisons performed were between the target group and the national average, excluding the target group. For example, we conducted the age comparison for $\mathrm{BC}$ by comparing the ages in $\mathrm{BC}$ to the ages in the 7 other provinces. Missing values were considered as their own group for categorical variables, and the counts of missing data were reported for measured variables. We conducted statistical analysis using $\mathrm{R}$ 3.5.2.

\section{Ethics approval}

All data received were anonymous and collected under a protocol approved by the University of Calgary Conjoint Health Research Ethics Board, with subsite ethics and legal agreements for data sharing between sites within the Canadian HBV Network. A waiver of consent was obtained from local research ethics boards or under section 50 of the Health Information Act of Alberta, or both, or patients provided signed informed consent to participate.

\section{Results}

\section{Patient characteristics and genotypes}

Clinical and demographic data were submitted for 9380 patients nationwide (Table 1). Most patients (5193 [55.4\%]) were men. The median age was 48 years. Ethnicity data were available for 7858 patients, of whom 5803 (73.8\%) were Asian, 916 (11.6\% black), 914 (11.6\%) white, and 225 (2.9\%) other (including Indigenous/First Nations). Just over half (521 [53.2\%] of the 980 patients with available HBV genotype data had genotype B or C infection (Table 2), as expected given the predominantly Asian origin of the patients.

\section{Hepatitis B virus disease status, fibrosis and antiviral therapy}

Most patients with available data (5556/6796 [81.8\%]) tested HBeAg negative, and 2319/2820 (82.2\%) had HBV DNA levels less than $2000 \mathrm{IU} / \mathrm{mL}$ (10 000 virus genome copies/ $\mathrm{mL}$ ) (Table 1). A substantial proportion (779/4260 [18.3\%]) had documented stage 2 or greater fibrosis (METAVIR score) based on liver stiffness measurement (FibroScan score $>7.3 \mathrm{kPa}$, data not shown). The most common antiviral therapy used at any time was tenofovir disoproxil fumarate (1655 patients [17.6\%]), followed by lamivudine (1434 $[15.3 \%])$ and entecavir (548 [5.8\%]). Interprovincial differences were noted in antiviral treatment regimen, with a higher proportion of patients in BC and Ontario than in other provinces receiving first-generation nucleos(t)ide analogs (i.e., lamivudine).

\section{Clinical characteristics according to hepatitis B virus genotype}

Compared to all other genotypes, patients with HBV genotype $\mathrm{C}$ were more likely to be $\mathrm{HBeAg}$ positive, have more advanced liver fibrosis (> stage 2 ) and receive nucleos $(\mathrm{t})$ ide antiviral therapy.

\section{Demographic and clinical characteristics according to sex and age}

Analysis of available clinical data for sex- and age-related differences showed that patients aged 40 years or more were more likely than those aged less than 40 to show increased liver fibrosis (> stage 2), whereas those aged less than 40 were more likely than those aged 40 or more to be HBeAg positive (Table 3).

\section{Interpretation}

In this cross-sectional, retrospective descriptive study of 9380 patients from 8 provincial health care jurisdictions, both academic and community clinics, we found that the majority of people with chronic hepatitis B were older, male, Asian and HBeAg-negative, and had HBV genotype B or C infection. Notable proportions had an HBV DNA level greater than $2000 \mathrm{IU} / \mathrm{mL}$ and stage 3 or higher fibrosis, which are important indicators regarding the need for antiviral therapy. Many patients received long-term therapy, but there were interprovincial differences between nucleos(t)ide analogue use (i.e., lamivudine v. tenofovir disoproxil/entecavir), likely owing to historic provincial disparities in access to secondgeneration therapy. Among 980 people with available genotype data, we noted significant differences between HBV genotype $\mathrm{C}$ clinical characteristics (higher fibrosis stage, higher alanine aminotransferase levels and higher rates of $\mathrm{HBeAg}$ positivity) compared to other genotypes.

These findings are consistent with those from studies of $\mathrm{HBV}$ genotype and more severe liver fibrosis in HBV genotype C (v. B) from Asian cohort studies. ${ }^{12}$ Our data also provide important comparisons across all reported genotypes in 1 country, which is not feasible in jurisdictions with less ethnic 
Table 1: Demographic characteristics, liver/hepatitis B virus test results, fibrosis and antiviral therapy of Canadians with chronic hepatitis $B$, by province

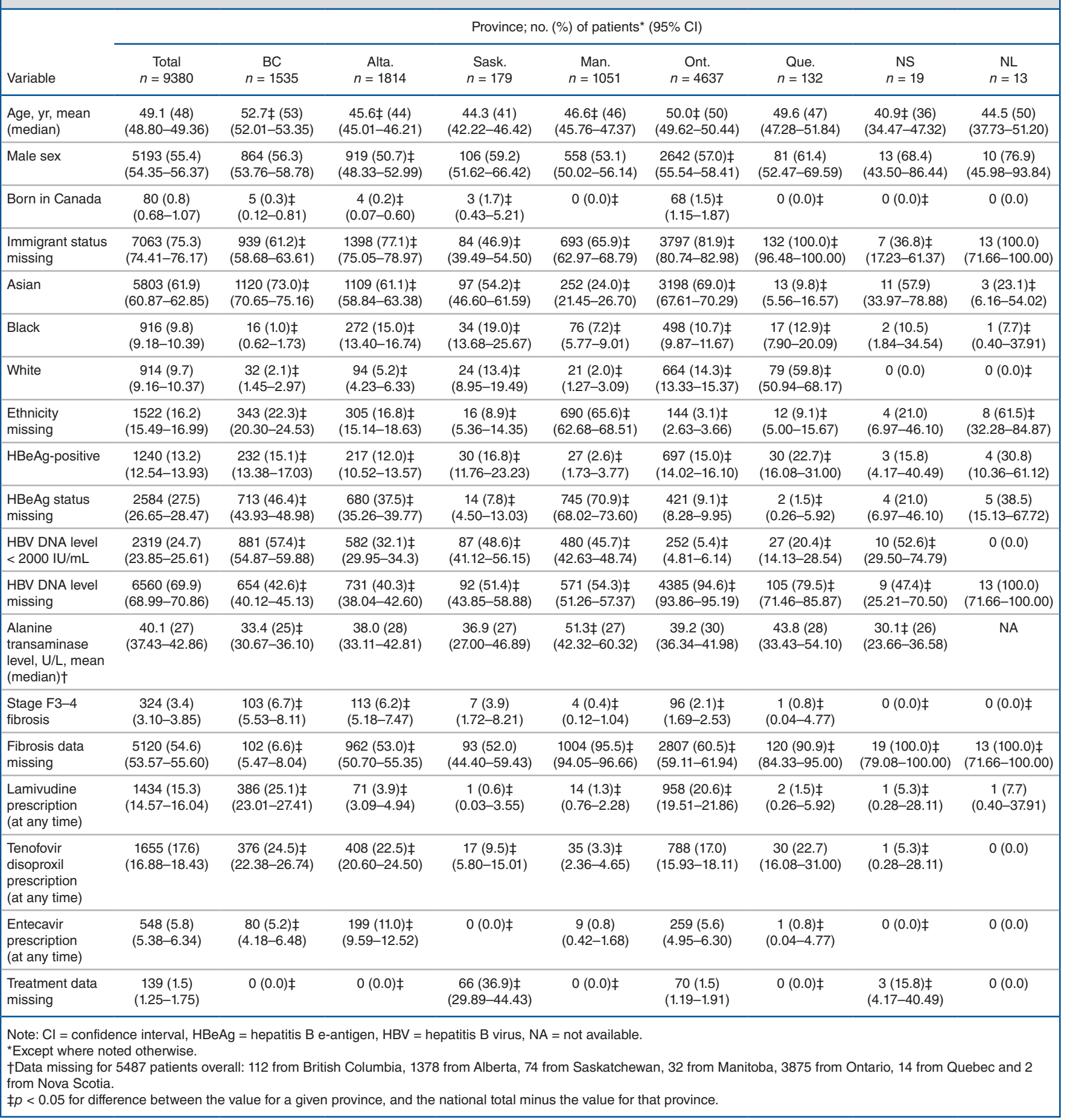

diversity. Most patients tested in the current study were $\mathrm{HBeAg}$ negative. Being negative for HBeAg may be due to the presence of precore and basal core promoter mutations in the viral genome and is associated with the development of cirrhosis or hepatocellular carcinoma, or both, in Asian cohort studies. ${ }^{13}$ Data on HBV included results of standard clinical tests (HBV DNA level and HBeAg status), ${ }^{11,13}$ as analysis for muta- tions associated with $\mathrm{HBeAg-negative} \mathrm{disease} \mathrm{is} \mathrm{not} \mathrm{available}$ or usually needed in routine clinical practice to assess need for treatment. Most of the data were contributed for patients residing in urban centres and from tertiary referral clinics in regions with high rates of immigration. ${ }^{11}$ Universal childhood vaccination in Nunavut has led to a significant decline in the prevalence of chronic infection in Inuit populations. ${ }^{8}$ This 
Table 2: Demographic characteristics, liver/hepatitis B virus test results, fibrosis and treatment of Canadians with chronic hepatitis $B$, by hepatitis $B$ virus genotype

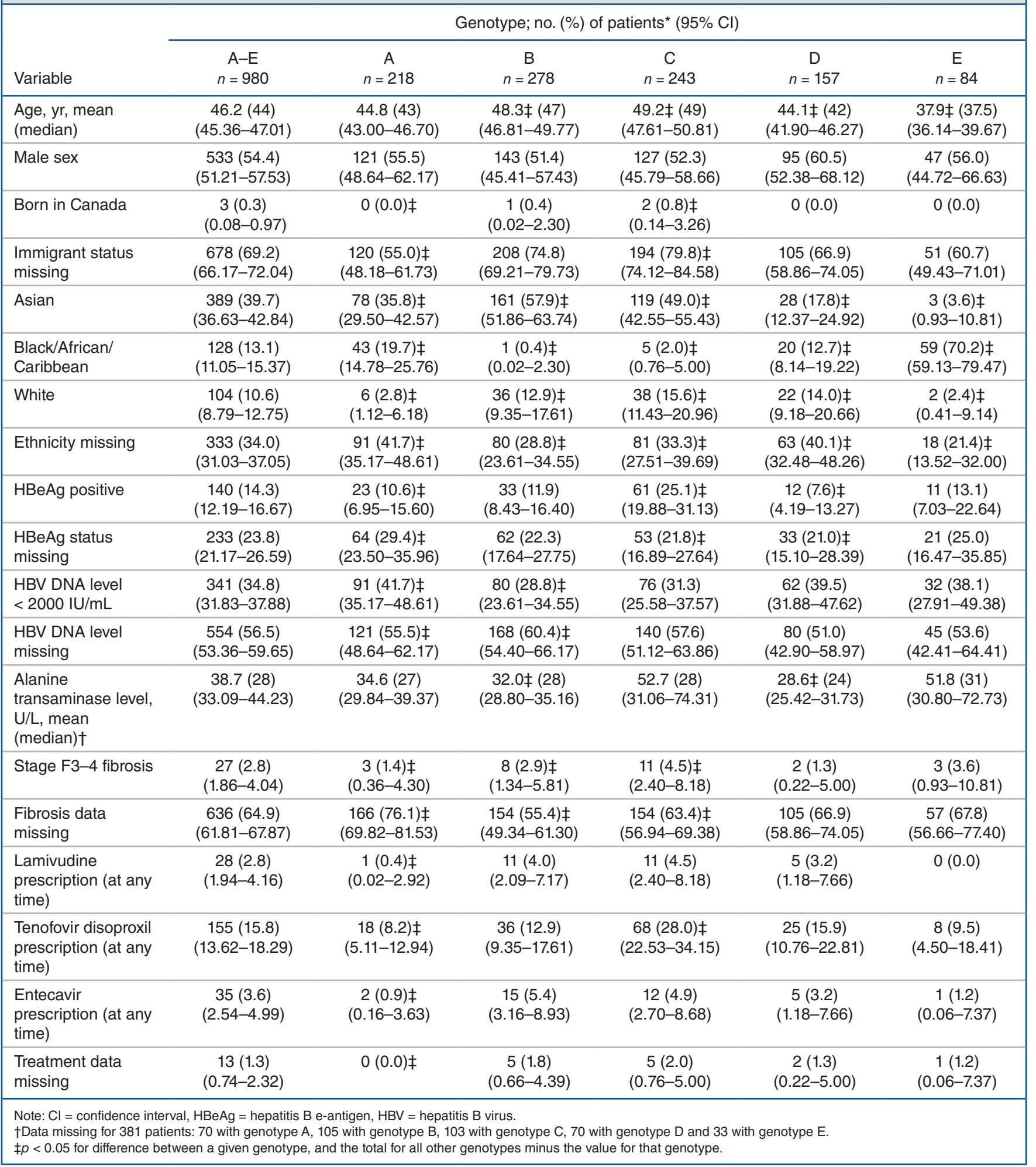

situation is mirrored in the current study, which did not show a substantial number of people with chronic hepatitis B in Canadian Indigenous populations $(<1 \%$ reported, data not shown). The baseline demographic and clinical data reported in the present study are similar to those reported by the Hepatitis B Research Network, a cooperative network of investigators from the United States and Canada, which found that $50 \%$ of adults were men, the median age was 42 years, and 


\begin{tabular}{|c|c|c|c|c|}
\hline \multirow[b]{2}{*}{ Variable } & \multicolumn{4}{|c|}{ No. $(\%)$ of patients* $(95 \% \mathrm{Cl})$} \\
\hline & $\begin{array}{c}\text { Men } \\
n=5193\end{array}$ & $\begin{array}{l}\text { Women } \\
n=4187\end{array}$ & $\begin{array}{c}\text { Age }<40 y r \\
n=2621\end{array}$ & $\begin{array}{c}\text { Age } \geq 40 \mathrm{yr} \\
n=6759\end{array}$ \\
\hline $\begin{array}{l}\text { Age, yr, mean } \\
\text { (median) }\end{array}$ & $\begin{array}{c}49.9 \ddagger(50) \\
(49.56-50.30)\end{array}$ & $\begin{array}{c}48.0 \ddagger(47) \\
(47.59-48.46)\end{array}$ & $\begin{array}{c}32.7 \S(33) \\
(32.48-32.85)\end{array}$ & $\begin{array}{c}55.4 \S(54) \\
(55.19-55.7)\end{array}$ \\
\hline Male sex & $\begin{array}{c}5193(100.0) \ddagger \\
(99.91-100.00)\end{array}$ & $-\ddagger$ & $\begin{array}{c}1260(48.1) \S \\
(46.15-50.01)\end{array}$ & $\begin{array}{l}3933(58.2) \S \\
(57.00-59.37)\end{array}$ \\
\hline Born in Canada & $\begin{array}{c}47(0.9) \\
(0.67-1.21)\end{array}$ & $\begin{array}{c}33(0.8) \\
(0.55-1.12)\end{array}$ & $\begin{array}{c}22(0.8) \S \\
(0.54-1.29)\end{array}$ & $\begin{array}{c}58(0.8) \S \\
(0.66-1.12)\end{array}$ \\
\hline $\begin{array}{l}\text { Immigrant status } \\
\text { missing }\end{array}$ & $\begin{array}{c}3943(75.9) \\
(74.74-77.08)\end{array}$ & $\begin{array}{c}3120(74.5) \\
(73.16-75.83)\end{array}$ & $\begin{array}{l}1922(73.3) \S \\
(71.59-75.01)\end{array}$ & $\begin{array}{l}5141(76.1) \S \\
(75.02-77.07)\end{array}$ \\
\hline Asian & $\begin{array}{c}3147(60.6) \ddagger \\
(59.25-61.93)\end{array}$ & $\begin{array}{l}2656 \text { (63.4)‡ } \\
(61.95-64.89)\end{array}$ & $\begin{array}{c}1510(57.6) \S \\
(55.69-59.51)\end{array}$ & $\begin{array}{c}4293(63.5) \S \\
(62.35-64.66)\end{array}$ \\
\hline $\begin{array}{l}\text { Black/African/ } \\
\text { Caribbean }\end{array}$ & $\begin{array}{c}516(9.9) \ddagger \\
(9.14-10.79)\end{array}$ & $\begin{array}{c}400(9.6) \ddagger \\
(8.69-10.49)\end{array}$ & $\begin{array}{c}433(16.5) \S \\
(15.13-18.01)\end{array}$ & $\begin{array}{c}483(7.1) \S \\
(6.55-7.79)\end{array}$ \\
\hline White & $\begin{array}{c}562(10.8) \ddagger \\
(10.00-11.71)\end{array}$ & $\begin{array}{l}352(8.4) \ddagger \\
(7.59-9.30)\end{array}$ & $\begin{array}{l}168(6.4) \S \\
(5.52-7.43)\end{array}$ & $\begin{array}{c}746(11.0) \S \\
(10.30-11.81)\end{array}$ \\
\hline Ethnicity missing & $\begin{array}{c}834(16.1) \ddagger \\
(15.08-17.09)\end{array}$ & $\begin{array}{c}688(16.4) \ddagger \\
(15.33-17.60)\end{array}$ & $\begin{array}{c}427(16.3) \S \\
(14.91-17.77)\end{array}$ & $\begin{array}{c}1095(16.2) \S \\
(15.33-17.11)\end{array}$ \\
\hline HBeAg positive & $\begin{array}{c}659(12.7) \ddagger \\
(11.80-13.63)\end{array}$ & $\begin{array}{c}581(13.9) \ddagger \\
(12.85-14.97)\end{array}$ & $\begin{array}{c}578(22.0) \S \\
(20.49-23.70)\end{array}$ & $\begin{array}{c}662(9.8) \S \\
(9.10-10.53)\end{array}$ \\
\hline HBeAg status missing & $\begin{array}{c}1384(26.6) \ddagger \\
(25.46-27.88)\end{array}$ & $\begin{array}{c}1200(28.7) \ddagger \\
(27.30-30.06)\end{array}$ & $\begin{array}{c}747(28.5) \S \\
(26.79-30.28)\end{array}$ & $\begin{array}{c}1837(27.2) \S \\
(26.12-28.26)\end{array}$ \\
\hline $\begin{array}{l}\text { HBV DNA level } \\
<2000 \mathrm{IU} / \mathrm{mL}\end{array}$ & $\begin{array}{c}1235(23.8) \\
(22.63-24.97)\end{array}$ & $\begin{array}{c}1084(25.9) \\
(24.57-27.25)\end{array}$ & $\begin{array}{c}681(26.0) \S \\
(24.32-27.72)\end{array}$ & $\begin{array}{c}1638(24.2) \S \\
(23.22-25.28)\end{array}$ \\
\hline $\begin{array}{l}\text { HBV DNA level } \\
\text { missing }\end{array}$ & $\begin{array}{c}3673(70.7) \\
(69.47-71.96)\end{array}$ & $\begin{array}{c}2887(69.0) \\
(67.52-70.35)\end{array}$ & $\begin{array}{c}1776(67.8) \S \\
(65.93-69.54)\end{array}$ & $\begin{array}{c}4784(70.8) \S \\
(69.68-71.86)\end{array}$ \\
\hline $\begin{array}{l}\text { Alanine transaminase } \\
\text { level, U/L, mean } \\
\text { (median) } \dagger\end{array}$ & $\begin{array}{c}48.2 \ddagger(31) \\
(43.45-52.86)\end{array}$ & $\begin{array}{c}30.5 \ddagger(22) \\
(28.66-32.43)\end{array}$ & $\begin{array}{c}42.5(27) \\
(36.27-48.67)\end{array}$ & $\begin{array}{c}39.3(27) \\
(36.34-42.18)\end{array}$ \\
\hline Stage F3-4 fibrosis & $\begin{array}{c}232(4.5) \\
(3.93-5.07)\end{array}$ & $\begin{array}{c}92(2.2) \\
(1.78-2.70)\end{array}$ & $\begin{array}{c}37(1.4) \S \\
(1.01-1.96)\end{array}$ & $\begin{array}{c}287(4.2) \S \\
(3.78-4.76)\end{array}$ \\
\hline Fibrosis data missing & $\begin{array}{c}2753(53.0) \\
(51.64-54.38)\end{array}$ & $\begin{array}{c}2367(56.5) \\
(55.01-58.04)\end{array}$ & $\begin{array}{c}1601(61.1) \S \\
(59.18-62.95)\end{array}$ & $\begin{array}{c}3519(52.1) \S \\
(50.86-53.26)\end{array}$ \\
\hline $\begin{array}{l}\text { Lamivudine } \\
\text { prescription (at any } \\
\text { time) }\end{array}$ & $\begin{array}{c}926(17.8) \ddagger \\
(16.81-18.91)\end{array}$ & $\begin{array}{c}508(12.1) \ddagger \\
(11.17-13.17)\end{array}$ & $\begin{array}{l}217(8.3) \S \\
(7.27-9.42)\end{array}$ & $\begin{array}{c}1217(18.0) \S \\
(17.10-18.95)\end{array}$ \\
\hline $\begin{array}{l}\text { Tenofovir disoproxil } \\
\text { prescription (at any } \\
\text { time) }\end{array}$ & $\begin{array}{c}1087(20.9) \ddagger \\
(19.84-22.07)\end{array}$ & $\begin{array}{c}568(13.6) \ddagger \\
(12.55-14.65)\end{array}$ & $\begin{array}{c}350(13.4) \S \\
(12.09-14.73)\end{array}$ & $\begin{array}{c}1305 \text { (19.3)§ } \\
(18.38-20.27)\end{array}$ \\
\hline $\begin{array}{l}\text { Entecavir prescription } \\
\text { (at any time) }\end{array}$ & $\begin{array}{l}350(6.7) \ddagger \\
(6.08-7.46)\end{array}$ & $\begin{array}{c}198(4.7) \ddagger \\
(4.12-5.43)\end{array}$ & $\begin{array}{c}93(3.5) \S \\
(2.89-4.35)\end{array}$ & $\begin{array}{l}455(6.7) \S \\
(6.15-7.36)\end{array}$ \\
\hline $\begin{array}{l}\text { Treatment data } \\
\text { missing }\end{array}$ & $\begin{array}{c}90(1.7) \ddagger \\
(1.40-2.14)\end{array}$ & $\begin{array}{c}49(1.2) \ddagger \\
(0.88-1.56)\end{array}$ & $\begin{array}{c}35(1.3) \S \\
(0.95-1.87)\end{array}$ & $\begin{array}{c}104(1.5) \S \\
(1.26-1.87)\end{array}$ \\
\hline \multicolumn{5}{|c|}{$\begin{array}{l}\text { Note: } \mathrm{Cl}=\text { confidence interval, } \mathrm{HBeAg}=\text { hepatitis } \mathrm{B} \text { e-antigen, } \mathrm{HBV}=\text { hepatitis } \mathrm{B} \text { virus. } \\
{ }^{*} \mathrm{Except} \text { where noted otherwise. } \\
\text { †Data missing for } 3078 \text { men, } 2422 \text { women, } 1556 \text { patients aged less than } 40 \text { years and } 3944 \text { patients aged } 40 \text { years or more. } \\
\ddagger \neq<0.05 \text { for difference between men and women. } \\
\S p<0.05 \text { for difference between patients aged less than } 40 \text { years and those aged } 40 \text { years or more. }\end{array}$} \\
\hline
\end{tabular}

$74 \%$ of the cohort were HBeAg-negative. ${ }^{14}$ In addition, our HBV genotype data are similar to those reported by the Hepatitis B Research Network (mainly B [39\%] and C [33\%], followed by A [18\%], D [8\%] and $\mathrm{E}[3 \%[)$, which also reflected the largely foreign-born population of Asian and Africans. ${ }^{14}$ However, the report did not include treatment information, and all fibrosis data were based on liver histopathological examination or serum-based markers of liver 
fibrosis (FibroTest or aspartate-aminotransferase-to-platelet ratio index [APRI]), as transient elastography was approved in the United States only relatively recently.

Our data highlight regional variations in $\mathrm{HBV}$ disease management that can inform policy-makers of areas where best practice can be implemented. Under the Canada Health Act, universal health care is publicly funded, and all Canadians should have reasonable access to medically necessary services. ${ }^{15}$ However, "medically necessary" is not specifically defined in the act, and health care spending and services are implemented by provincial/territorial government health care boards. This has led to substantial variation in public access to prescription medications and even in childhood HBV vaccination schedules. For example, Alberta and Quebec have included second-generation nucleos(t)ide analogues as first-line therapy for HBV for almost a decade, yet these drugs were not approved on public drug benefits list in Ontario until recently and are still not covered by BC pharmacare unless patients have advanced fibrosis. The World Health Organization recommends that all infants receive their first dose of $\mathrm{HBV}$ vaccine as soon as possible after birth, as the greatest risk of chronic hepatitis B is within the first 5 years of life. ${ }^{1}$ Only 5 provinces (BC, Alberta [since September 2018], Quebec, New Brunswick and Prince Edward Island) and the territories offer universal infant $\mathrm{HBV}$ vaccination. Universal HBV screening during pregnancy is mandatory in many provinces but is only "strongly recommended" in Ontario, although it is widely implemented as good clinical practice. ${ }^{16}$ Although there has been considerable public health focus on hepatitis $\mathrm{C}$ and HIV infection in Canada, hepatitis B remains underappreciated and underfunded, and there is a lack of awareness of disease burden and complexity of management, and a need for better treatments. ${ }^{17}$ According to the Ontario Burden of Infectious Diseases Study, HBV was the fifth-ranked pathogen causing substantial health-adjusted life-years lost. ${ }^{18}$ Modelling data showed that immigrants with hepatitis B in Canada lost an average of 4.6 life-years, with higher lifetime risk of end-stage liver disease. ${ }^{19}$ Current immigration trends and aging of the Canadian population mean that it is imperative that uniform, structural programs be developed for identification (screening), education and access to care for Canadians at risk for HBV infection and possible lifethreatening consequences. The Canadian HBV Network is committed to conducting longitudinal, prospective and rigorous epidemiological studies on HBV infection in Canada. Our network is working to establish global partnerships such as with the International Coalition to Eliminate HBV (https://www.ice-hbv.org), which includes more than 50 scientists from 21 countries.

\section{Limitations}

The data may not represent patients who are not engaged in care. In addition, to date, there are limited genotype data from participating sites in BC, Ontario and Quebec, which have large populations of patients with hepatitis B. However, ongoing robust prospective data collection by Canadian
HBV Network investigators will help address these data gaps in future studies. The data completeness may be affected by underreporting and referral bias (i.e., patients with symptoms of advanced liver disease are more likely to be referred for treatment by their primary care provider than asymptomatic patients); however, patients with cirrhosis and hepatocellular carcinoma are often asymptomatic, and many people are referred too late or present with nonspecific symptoms..$^{20}$ All study investigators highlight consistent or increasing number of patients in their clinical practice needing treatment.

\section{Conclusion}

The current study provides data on the demographic and clinical characteristics, virological outcomes and antiviral treatment in people with chronic hepatitis B in Canada. Hepatitis $\mathrm{B}$ is an ongoing and important cause of morbidity and mortality in Canada. Country-specific epidemiological data will inform the development of programs to eliminate hepatitis $\mathrm{B}$ as a public health threat and ultimately achieve a cure for the disease. The data from this study will inform global research on the impact of $\mathrm{HBV}$, even in wealthy countries such as Canada.

\section{References}

1. Hepatitis B: Fact sheet no. 204. Geneva: World Health Organization; 2008, updated 2019 July 18.

2. Schweitzer A, Horn J, Mikolajczyk RT, et al. Estimations of worldwide prevalence of chronic hepatitis B virus infection: a systematic review of data published between 1965 and 2013. Lancet 2015;386:1546-55.

3. Lin CL, Kao JH. Hepatitis B virus genotypes and variants. Cold Spring Harb Perspect Med 2015;5:a021436.

4. Brief report: bepatitis B infection in Canada. Ottawa: Public Health Agency of Canada; 2011.

5. Report on Hepatitis B and C in Canada: 2013. Ottawa: Public Health Agency of Canada; 2015. Available: http://publications.gc.ca/collections/collection_2016/ aspc-phac/HP37-22-2013-eng.pdf (accessed 2018 Sept. 4).

6. British Columbia annual summary of reportable diseases: 2014. Vancouver: BC Centre for Disease Control; 2015.

7. Sherman M. Liver disease in Canada: a crisis in the making - an assessment of liver disease in Canada. Markham (ON): Canadian Liver Foundation; 2013.

8. Huynh C, Minuk GY, Uhanova J, et al. Serological and molecular epidemiological outcomes after two decades of universal infant hepatitis B virus (HBV) vaccination in Nunavut, Canada. Vaccine 2017;35:4515-22.

9. 2016 census topic: immigration and ethnocultural diversity. Ottawa: Statistics Canada; 2017, updated 2019 May 15. Available: www12.statcan.gc.ca/census -recensement/2016/rt-td/imm-eng.cfm (accessed 2018 Sept. 4).

10. Lau KCK, Shaheen AA, Aspinall AA, et al. Hepatitis B virus testing and linkage to care in a Canadian urban tertiary referral centre: a retrospective cohort study. CMA7 Open 2017;5:E431-6.

11. Congly SE, Wong P, Al-Busafi SA, et al. Characterization of hepatitis B virus genotypes and quantitative hepatitis B surface antigen titres in North American tertiary referral liver centres. Liver Int 2013;33:1363-9.

12. Rajoriya N, Combet C, Zoulim F, et al. How viral genetic variants and genotypes influence disease and treatment outcome of chronic hepatitis B. Time for an individualised approach? Z Hepatol 2017;67:1281-97.

13. Wen J, Song C, Jiang D, et al. Hepatitis B virus genotype, mutations, human leukocyte antigen polymorphisms and their interactions in hepatocellular carcinoma: a multi-centre case-control study. Sci Rep 2015;5:16489.

14. Ghany MG, Perrillo R, Li R, et al.; Hepatitis B Research Network. Characteristics of adults in the Hepatitis B Research Network in North America reflect their country of origin and hepatitis B virus genotype. Clin Gastroenterol Hepatol 2015;13:183-92.

15. Romanov RJ, commissioner. Building on values: the future of health care in Canada - final report. Saskatoon: Privy Council; 2002. Available: http://publications. gc.ca/site/eng/237274/publication.html (accessed 2018 Sept. 4).

16. Biondi MJ, Lipton N, Marchand-Austin A, et al. P1-137: lack of prenatal $\mathrm{HBV}$ and HCV screening and follow-up in Ontario, Canada [abstract]. 7 Viral Hepat 2018;25:96.

17. Congly SE, Brahmania M. Variable access to antiviral treatment of chronic hepatitis B in Canada: a descriptive study. CMAf Open 2019;7:E182-9. 
18. Kwong JC, Ratnasingham S, Campitelli MA, et al. The impact of infection on population health: results of the Ontario Burden of Infectious Diseases Study. PLoS One 2012;7:e44103.

19. Wong WW, Woo G, Heathcote EJ, et al. Disease burden of chronic hepatitis B among immigrants in Canada. Can 7 Gastroenterol 2013;27:137-47.

20. Tsochatzis EA, Bosch J, Burroughs AK. Liver cirrhosis. Lancet 2014;383: 1749-61.

Affiliations: Cumming School of Medicine (Coffin, Lethebe, Congly, Haylock-Jacobs), University of Calgary, Calgary, Alta.; Division of Gastroenterology (Ramji, Ko), Department of Medicine, Faculty of Medicine, University of British Columbia, Vancouver, BC; Division of Infectious Diseases (Cooper), University of Ottawa, Ottawa Hospital Research Institute; Division of Gastroenterology (Kelly), Department of Medicine, University of Ottawa, Ottawa Hospital Research Institute, Ottawa, Ont.; Department of Medicine (Doucette, Ma), University of Alberta, Edmonton, Alta.; Division of Gastroenterology (P. Wong), Department of Medicine, McGill University, Royal Victoria Hospital, Montréal, Que.; LAIR Centre (Tam), Vancouver, BC; Department of Medicine (D. Wong, Janssen, Fung), University of Toronto, Toronto Centre for Liver Disease, Toronto, Ont.; Department of Medicine (A. Wong), University of Saskatchewan; Regina General Hospital (Ukabam), Regina, Sask.; Bailey Health Clinic (Bailey), Edmonton, Alta.; Department of Medicine (Tsoi), McMaster University, St. Joseph's Healthcare, Hamilton, Ont.; Vancouver Infectious Diseases Centre (Conway), Vancouver, BC; Division of Infectious Diseases (Barrett), Dalhousie University, Halifax, NS; Faculty of Medicine (Michalak), Memorial University of Newfoundland, St. John's, Nfld.; Department of Internal Medicine (Minuk, Uhanova, Miles, Kaita), University of Manitoba; National Microbiology Laboratory (Osiowy), Public Health Agency of Canada, Winnipeg, Man.

Competing interests: Carla Coffin reports investigator-initiated research grants/research materials from GlaxoSmithKline, Gilead Sciences, Arbutus Biopharma and Bristol-Myers Squibb, and educational grants from Merck, Gilead Sciences and Janssen Pharmaceutica. She is on the advisory board for Merck, Gilead Sciences and GlaxoSmithKline, and the Trial Guidance and Publication Committee for Spring Bank Pharmaceuticals, and has participated as a local site principal investigator in clinical trials for Gilead Sciences, Spring Bank Pharmaceuticals, Transgene and Janssen Pharmaceutica. Alnoor Ramji reports clinical investigator grants from Allergan, Arbutus Biopharma, Gilead Sciences, Janssen Pharmaceutica, Intercept Pharmaceuticals, Norvartis, Merck, Spring Bank Pharmaceuticals and Assembly Biosciences; personal fees from AbbVie, Gilead Sciences, Intercept Pharmaceuticals, Lupin and Merck; and grants from AbbVie, Celgene Corporation, Gilead Sciences, Janssen Pharmaceutica, Intercept Pharmaceuticals and Merck. Karen Doucette reports a grant from Gilead Sciences. Keith Tsoi reports personal fees from Gilead Sciences, Merck, AbbVie and Intercept Pharmaceuticals, and nonfinancial support from
Gilead Sciences. Brian Conway reports grants and honoraria from AbbVie, Gilead Sciences, Indivior, Merck and Viiv Healthcare. He has acted as a consultant for these companies. Lisa Barrett reports grants from AbbVie and personal fees from AbbVie, Bristol-Myers Squibb, Gilead Sciences and ViiV Healthcare. Stephen Congly reports grants from Allergan, Gilead Sciences, Genfit, Boehringer Ingelheim and Bristol-Myers Squibb, and personal fees from Allergan. Edward Tam reports grants from AbbVie, Gilead Sciences, Merck, Intercept Pharmaceuticals and Janssen Pharmaceutica, and personal fees from AbbVie, Bristol-Myers Squibb, Gilead Sciences, Merck, Intercept Pharmaceuticals and Janssen Pharmaceutica. David Wong reports other funding from AbbVie, Merck and Gilead Sciences. Alex Wong reports grants and personal fees from Gilead Sciences. Harry Janssen reports grants from AbbVie, Bristol-Myers Squibb, Gilead Sciences, Janssen Pharmaceutica, MedImmune, Merck and Roche, and personal fees from AbbVie, Benitec Biopharma, Bristol-Myers Squibb, Gilead Sciences, Janssen Pharmaceutica, MedImmune, Roche, Arbutus Biopharma and Vir Biotechnology. Scott Fung reports speaking and teaching fees from Gilead Sciences and Bristol-Myers Squibb, and consulting fees from Gilead Sciences. No other competing interests were reported.

Contributors: Carla Coffin (Canadian HBV Network co-lead) conceived and designed the study, had overall responsibility for the conduct and coordination of the study, and drafted the manuscript. Carla Coffin, Scott Fung (Canadian HBV Network co-lead), Alnoor Ramji, Curtis Cooper, Hin Ko, Mang Ma, Carla Osiowy, Philip Wong (Steering Committee members), Edward Tam, David Wong, Alexander Wong, Sylvester Ukabam, Robert Bailey, Keith Tsoi, Brian Conway, Lisa Barrett, Tomasz Michalak, Stephen Congly, Gerald Minuk, Kelly Kaita, Erin Kelly, Harry Janssen and Julia Uhanova contributed to data collection. Sarah Haylock-Jacobs cleaned the data. Sarah Haylock-Jacobs and Brendan Lethebe analyzed the data. Carla Osiowy performed the quantitative hepatitis B virus surface antigen and genotype testing. All of the authors critically revised the manuscript for important intellectual content, approved the final version to be published and agreed to be accountable for all aspects of the work.

Funding: This study was funded by an infrastructure grant from the Canadian Foundation for Innovation/Alberta Advanced Education and Technology and an unrestricted research grant from Gilead Sciences, Canada.

Acknowledgements: The authors thank all investigators and coordinators from the Canadian HBV Network and all patients involved in the study.

Supplemental information: For reviewer comments and the original submission of this manuscript, please see www.cmajopen.ca/content/7/4/ E610/suppl/DC1. 